\title{
Phytochemical, nutraceutical and antioxidant studies of the aerial parts of Daucus carota L. (Apiaceae)
}

\author{
Emmanuel Ayodeji Ayeni $^{1 \star}$, Ahmed Abubakar ${ }^{1}$, Garba Ibrahim ${ }^{1}$, Vallada Atinga ${ }^{2}$, Zainab Muhammad ${ }^{1}$ \\ ${ }^{1}$ Department of Pharmacognosy and Drug Development, Ahmadu Bello University Zaria, Nigeria \\ ${ }^{2}$ Department of Pharmacognosy and Drug Development, Gombe State University, Gombe, Nigeria
}

\section{A R T I C L E I N F O}

Article Type:

Original Article

Article History:

Received: 9 October 2017

Accepted: 10 January 2018

\section{Keywords:}

Daucus carota

Carrot

Proximate

Antioxidant

Spectrophotometry

\begin{abstract}
A B S T RA C T
Introduction: Carrot is a rich source of anthocyanins, carotenoids, vitamins A, B and C. The aerial parts are used as livestock feed in some parts of Northern Nigeria with little or no scientific evidence of its nutritional potential. This study established the phytochemical, nutritional and antioxidant potentials of carrot aerial parts.

Methods: The proximate and elemental analyses of the aerial parts were determined using Association of Official Analyst Chemist (AOAC) method and 2,2-diphenyl-1-picrylhydrazyl (DPPH) method for quantification of antioxidant properties in the crude extracts.

Results: The preliminary phytochemical screening revealed presence of steroid/triterpenes, flavonoids, tannins and saponins in ethylacetate and methanol crude extracts. The proximate analysis revealed crude protein (14.59\%), lipid (10.37\%), fibre (9.07\%), carbohydrate $(51.81 \%)$, moisture $(10.23 \%)$ and the ash content $(12.99 \%)$. The aerial parts were rich in $\mathrm{P}(11.00 \mathrm{mg} / \mathrm{L})$, $\mathrm{Na}(5.38 \mathrm{mg} / \mathrm{L}), \mathrm{Fe}(3.19 \mathrm{mg} / \mathrm{L}), \mathrm{K}(2.25 \mathrm{mg} / \mathrm{L}), \mathrm{Ca}(2.02 \mathrm{mg} / \mathrm{L}), \mathrm{Mn}(1.15 \mathrm{mg} / \mathrm{L}), \mathrm{Mg}(1.02$ $\mathrm{mg} / \mathrm{L})$, As $(0.83 \mathrm{mg} / \mathrm{L})$, Se $(0.40 \mathrm{mg} / \mathrm{L}), \mathrm{Zn}(0.26 \mathrm{mg} / \mathrm{L}), \mathrm{Cu}(0.13 \mathrm{mg} / \mathrm{L}), \mathrm{Cd}(-0.02 \mathrm{mg} / \mathrm{L})$, $\mathrm{Cr}(0.02 \mathrm{mg} / \mathrm{L}), \mathrm{Ni}(0.17 \mathrm{mg} / \mathrm{L})$ and $\mathrm{Pb}(0.04 \mathrm{mg} / \mathrm{L})$. The antioxidant activity showed that ethylacetate and methanol extracts had EC50 of $86.89 \mathrm{ug} / \mathrm{mL}$ and $166.79 \mathrm{ug} / \mathrm{mL}$, respectively. Conclusion: Daucus carota aerial parts are rich in nutritional compositions and may be used as livestock feed supplements and also as vegetables for mankind. Its utilization could be incorporated in daily diets and boost food security in developing countries.
\end{abstract}

Implication for health policy/practice/research/medical education:

This study confirms the requisite for continuous search of rich edible foods in achieving zero hunger among developing countries. It looked inward in alternative sources of sustenance through conversion of peels from fruits, vegetables and other values added products into production of essential oils, nutraceuticals, food additives and its prospect in boosting food security in developing countries with significant poverty indices.

Please cite this paper as: Ayeni EA, Ahmed A, Ibrahim G, Vallada A, Muhammad Z. Phytochemical, nutraceutical and antioxidant studies of the aerial parts of Daucus carota L. (Apiaceae). J Herbmed Pharmacol. 2018;7(2):68-73. doi: 10.15171/ jhp.2018.12.

\section{Introduction}

Natural products especially from plants have led to drug developments (1). It is well-known that plants are the main sources of food, clothing, shelter, herbal beverages and drugs in health care management including Nigeria $(2,3)$. The World Health Organization (WHO) established that over $68 \%$ of the world population solely depends on medicinal plant to meet their health demands (4). Natural products especially from plant are always and readily available, inexpensive and utilizations are relevant to people cultures and origins (5). This expresses the potential of medicinal plants in achieving and attaining the global statutory quotes of health for all.
Antioxidant activities in plants have been contributed in delaying, preventing and removing the oxidative damages to target molecules (6). Such oxidative processes are dangerous for all living cells, especially those in proximity to sites where active oxygen is released by photosynthesis (7).

Carrot (Daucus carota L.) belongs to the family of Apiaceae (8). It is one of the edible root plants and a rich source of anthocyanins, carotenoids ( $\alpha, \beta, \chi$ carotene), vitamins A, B and C (8). All the parts of D. carota have been used traditionally as aphrodisiac, diuretic, antidiabetic, muscle and back pain reliever. Also the hot water extract of the leaf is taken orally as a uterine stimulant during 
parturition and has abortifacient potentials (9). Generally, some of the species possess antimicrobial activities and have been used in flavoring of alcoholic beverages (9). Commonly, the plants in Apiaceae family are known to possess antioxidant and anti-inflammatory activities, used in treating infections, respiratory ailments and have hepatoprotective activities (10). In Nigeria, carrot is called Karas among the Hausa, Karoti or Atoka in Yoruba and Karotu in Igbo (11). However, the D. carota aerial parts are usually thrown away after harvesting or after eating the edible root part and in some parts of Northern Nigeria the aerial part is used as components of livestock feed. The aim of the study is to establish the phytochemicals, nutritional and antioxidant potentials of the D. carota aerial parts and suggest its possible utilizations as vegetable.

\section{Materials and Methods}

Collection, identification and preparation of plant material The aerial parts of $D$. carota were collected from carrot sellers in Samaru market, Sabon Gari Local Government Area, Zaria, Nigeria. The whole plant (root inclusive) was identified by Mallam Namadi Sanusi, a Taxonomist in the Department of Botany, Ahmadu Bello University, Zaria and the voucher specimen was obtained and deposited in the herbarium unit (No: 12034) for future references. The foreign materials in the plant samples were removed, air dried for 5-6 days, pulverized and stored in a cleaned polythene bag for further use.

\section{Extraction of Daucus carota aerial parts}

The plant materials were successively extracted by cold maceration based on solvents polarity using n-hexane, ethyl-acetate and methanol, respectively (12).

\section{Chemicals and solvents}

All chemicals and reagents were of analytical grades (Sigma Aldrich, Lagos distributor, Nigeria). The instruments used included atomic emission spectrophotometer (MP-AES), flame emission spectrophotometer (A-Analyst-700) all from Agilent Company LTD and $\mathrm{HACH}$ Spectrophotometry (DR/4200) was used for phosphorus determination. All instruments were calibrated to standard before use.

Preliminary phytochemical screening of Daucus carota aerial parts

The n-hexane, ethyl acetate and methanol extracts of the plant aerial parts were subjected to preliminary phytochemical screening using standard methods for qualitative analysis of phytochemicals present in D. carota aerial parts (13).

\section{Test for saponins}

i. Frothing test: About $0.5 \mathrm{~g}$ of the extracts was shaken with water in a test tube followed by warming on a water bath. Frothing which persisted on warming was taken as an evidence for the presence of saponins.

ii. Hemolysis test: $2 \mathrm{~mL}$ of sodium chloride $(1.8 \%$ solution in distilled water) was added to two test tubes $\mathrm{A}$ and $\mathrm{B}$. Then, $2 \mathrm{~mL}$ of distilled water was added to test tube $\mathrm{A}, 2 \mathrm{~mL}$ of the extract was added to test tube B. Five drops of blood were added to each tube and the tubes were inverted gently to mix the contents. Hemolysis in tube B containing the extract but not in tube A (i.e. control), indicated the presence of saponins in the extract.

Test for steroid/triterpenes

i. Lieberman-Buchard test: A small portion of each extract was dissolved in chloroform. Then, volume of acetic anhydride was added, followed by concentrated sulphuric acid down the side of the test tube. The mixture was observed for the presence of a brown ring at the interphase which indicated the presence of triterpenes.

ii. Salkowski test: A small amount of each extract was dissolved in $1 \mathrm{~mL}$ chloroform and $1 \mathrm{~mL}$ of concentrated sulphuric acid was added down the side of the test tube. Formation of red coloration at the interphase was observed as an indication of presence of sterols.

Test for flavonoids

i. Shinoda test: About $0.5 \mathrm{~g}$ of each extract was dissolved in $5 \mathrm{~mL}$ of $95 \%$ ethanol, warmed and filtered. Three pieces of magnesium chips were added followed by five drops of concentrated hydrochloric acid. Pink or slight orange color indicated the presence of flavonoids.

ii. Sodium hydroxide test: Few quantities of each extract were dissolved in water and filtered; $2 \mathrm{~mL}$ of $10 \%$ aqueous sodium hydroxide solution was added. In the solution, the presence of yellow color, a change in color from yellow to colorless on addition of dilute hydrochloric acid, indicated and confirmed the presence of flavonoids.

Test for Tannins

i. Ferric chloride test: $0.5 \mathrm{~g}$ of each extract was stirred with $10 \mathrm{~mL}$ distilled water and filtered. Two drops of $1 \%$ ferric chloride solution was added to $2 \mathrm{~mL}$ of the filtrate. Formation of a blue-black color indicated the presence of tannins.

ii. Lead sub-acetate test: To a small quantity of each extract, three drops of lead sub-acetate solution were added. The solution observed the presence of green precipitate which confirmed the presence of tannins.

Test for alkaloids

About $0.5 \mathrm{~g}$ of each extract was stirred with $5 \mathrm{~mL}$ of $1 \%$ 
aqueous hydrochloric acid in a water bath and filtered. Ammonia solution was added to the filtrate until it is basic, then chloroform was added, gently shaken to allow separation. The chloroform layer was collected and dilute $\mathrm{HCl}$ was added, gently shaken to allow separation and the aqueous layer was divided into three portions.

i. To the first portion, few drops of freshly prepared Dragendorff reagent was added and observed for formation of orange to brownish precipitates.

ii. To the second portion, one drop of Mayer's reagent was added and observed for formation of white to yellowish or cream color precipitates.

iii. To the third portion, $1 \mathrm{~mL}$ of Wagner's reagent was added to give a brown or reddish or reddish-brown precipitates, which indicated the presence of alkaloids.

Test for anthraquinone

i. Borntrager's test: The extracts were shaken with 10 $\mathrm{mL}$ of chloroform, the content of each extract was filtered and $5 \mathrm{~mL}$ of $10 \%$ ammonia solution was added to the filtrate, the mixture was shaken. Pink or slight red colour in the upper part of the aqueous layer indicated the presence of free anthraquinone.

ii. Modified Bontrager's test: The extracts were boiled with $10 \mathrm{~mL}$ of aqueous sulphuric acid and filtered hot. The filtrate, after cooling to room temperature, was shaken with $5 \mathrm{~mL}$ chloroform, the chloroform layer was separated and to half of its volume, $10 \%$ ammonium hydroxide was added. A pink, red or violet coloration in the ammonia phase (lower phase) indicated the presence of combined anthraquinone or anthraquinone derivatives.

Test for cardiac glycosides

i. Keller-Kiliani test: 0.5 g of each extract was dissolved in $2 \mathrm{~mL}$ of glacial acetic acid containing one drop of ferric chloride solution. Then $1 \mathrm{~mL}$ of concentrated sulphuric acid was added, gently. Brown ring obtained at the interphase indicated the presence of deoxy sugar characteristic of cardenolides.

ii. Kedde's test: Few drops of $2 \%$ solution of 3, 5-dinitrobenzoic acid in 95\% alcohol were added to small portion of filtrate. A solution of $5 \%$ sodium hydroxide was also added to make the solution alkaline appearance. The presence purple-blue colour indicated the presence of cardenolides and the absence confirmed absence of cardenolides.

Thin Layer Chromatography profiles of the aerial parts extracts

Thin layer chromatography (TLC) of stationary phase (Silica Gel $60 \mathrm{~F}_{254}$ ) pre-coated plates (Merck, Germany) of $0.25 \mathrm{~mm}$ thickness was used. The spotting was done manually and the TLC aluminum plates were developed at room temperature in ascending order of chromatography technique inside saturated solvents chromatographic tank. Separations were observed moving from the solvent baseline to the solvent front in the chromatographic tank. The chromatograms were allowed to dry and then observed under iodine tank before spraying with $\mathrm{P}$-anisaldehyde as general spraying agent and placed in the oven at $120^{\circ} \mathrm{C}$ for 2 minutes (14). The best solvent used was hexane:ethylacetate (9:1) while hexane:ethylacetate (5:5) was used for the ethylacetate extract and butanol:acetic acid:water (8:1:1) was used to develop the methanol extract. The $\mathrm{R}_{\mathrm{f}}$ values of each spot observed were calculated and the chromatograms were photomicrograph.

Determination of proximate analyses

The proximate analysis of the aerial parts was carried out to know the nutritional proportion of carbohydrates, fats (lipid), crude proteins, moisture and ash contents using Association of Official Analytical Chemists (AOAC) method. Percentages were used for result presentation and all samples were replicated three times for statistical analysis alongside with their standard deviation (15).

Determination of elemental analysis of Daucus carota aerial parts

Acid digestion of the samples: $0.5 \mathrm{~g}$ of the D. carota aerial parts was weighed into 10 different beakers each of $50 \mathrm{~mL}$, to which $6 \mathrm{~mL}$ of a mixture of perchloric acid $\left(\mathrm{HClO}_{4}\right)$ and nitric acid $\left(\mathrm{HNO}_{3}\right)$ in 1:5 ratio were added. The 10 beakers used were placed in an open space for 2 hours and a mixture of hydrochloric acid $(\mathrm{HCl})$ and nitric acid $\left(\mathrm{HNO}_{3}\right)$ in 1:1 ratio was added to each beaker. It was kept on a hot plate at $300^{\circ} \mathrm{C}$ for 4 hours. After the contents of beakers dried, $5 \mathrm{~mL}$ of $\mathrm{HCl}$ was added to each beaker and was kept on the hot plate until the entire liquid content in the beakers evaporated. Then, $5 \mathrm{~mL}$ of de-ionized water was added to each beaker and the solutions were poured in sterile bottles and tested for the quantification of the metals $(16,17)$. The concentrations of $\mathrm{Fe}, \mathrm{Mg}, \mathrm{Zn}, \mathrm{Cu}, \mathrm{K}$ and $\mathrm{Na}$ were read using the flame atomic spectrophotometer (AA500-model). HACH Spectrophotometry (DR/4200) was used for phosphorus determination and Atomic Emission Spectrophotometer (A-ES- Agilent Company) was used for other elements detected.

The antioxidant activities of the extracts were carried out according to an established method $(18,19)$. The antioxidant effective concentrations were compared with gallic acid as the positive control.

\section{Statistical analysis}

All results are presented in tables and figures. The mean and standard deviation (SD) were in three replicates and analyzed using the Statistical Package for Social Sciences (SPSS version 20.0 Chicago).

\section{Results}

The preliminary phytochemical screening in the n-hexane, ethylacetate and methanol extracts revealed the absence 
of alkaloids, cardiac glycosides and anthraquinone while steroids/triterpenes was present. The ethyl acetate and methanol extracts showed the presence of saponins, flavonoids and tannins (Table 1 ).

The proximate composition revealed that the aerial part contained carbohydrate (51.81\%), crude protein (14.59\%),

Table 1. Preliminary phytochemical screening of Daucus carota aerial part

\begin{tabular}{|c|c|c|c|}
\hline Phytochemical constituents & NDCA & EDCA & MDCA \\
\hline \multicolumn{4}{|l|}{ Alkaloids } \\
\hline Dragendorf test & - & - & - \\
\hline Wagner's test & - & - & - \\
\hline Mayers test & - & - & - \\
\hline \multicolumn{4}{|l|}{ Cardiac glycosides } \\
\hline Keller-killani & - & - & - \\
\hline Keddes test & - & - & - \\
\hline \multicolumn{4}{|l|}{ Saponins } \\
\hline Frothing test & - & + & + \\
\hline Haemolysis test & - & + & + \\
\hline \multicolumn{4}{|l|}{ Flavonoids } \\
\hline Shinodas test & - & + & + \\
\hline Lead acetate test & - & + & + \\
\hline \multicolumn{4}{|l|}{ Anthraquinones } \\
\hline Bontragers test & - & - & - \\
\hline Modified bontragers test & - & - & - \\
\hline \multicolumn{4}{|l|}{ Tannins } \\
\hline $\mathrm{Fecl}_{3}$ & - & + & + \\
\hline Lead acetate test & - & + & + \\
\hline \multicolumn{4}{|l|}{ Steroid/triterpenes } \\
\hline Liberman buchard & + & + & + \\
\hline Salkwoski test & + & + & + \\
\hline
\end{tabular}

Key: (-) Absent; (+) Present

NDCA, n-hexane extract; EDCA, ethylacetate extract; MDCA, methanol extract. lipid $(10.37 \%)$, fibre $(9.07 \%)$, moisture content $(5.67 \%)$ and ash content (11.60\%), respectively (Table 2 ).

The antioxidant activity showed that ethylacetate and methanol extracts had $\mathrm{EC}_{50}$ of $86.89 \mathrm{~mol} / \mathrm{L}$ and 166.79 $\mathrm{mol} / \mathrm{L}$, respectively (Table 3 ).

The aerial parts were rich in macro and trace elements including, $\mathrm{P}$ (11.00 mg/L), Na (5.38 mg/L), Fe (3.19 mg/L), $\mathrm{K}(2.25 \mathrm{mg} / \mathrm{L}), \mathrm{Ca}(2.02 \mathrm{mg} / \mathrm{L}), \mathrm{Mn}(1.15 \mathrm{mg} / \mathrm{L}), \mathrm{Mg}(1.02$ $\mathrm{mg} / \mathrm{L})$, As (0.83 mg/L), Se (0.40 mg/L), Zn (0.26 mg/L), $\mathrm{Cu}(0.13 \mathrm{mg} / \mathrm{L}), \mathrm{Cd}(-0.02 \mathrm{mg} / \mathrm{L}), \mathrm{Cr}(0.02 \mathrm{mg} / \mathrm{L}), \mathrm{Ni}(0.17$ $\mathrm{mg} / \mathrm{L})$ and $\mathrm{Pb}(0.04 \mathrm{mg} / \mathrm{L})$ (Figure 1$)$.

The $n$-hexane extract showed 11 spots alongside with $R_{f}$ values of $0.09,0.17,0.23,0.36,0.40,0.46,0.50,0.57,0.60$, 0.79 and 0.91 , the ethylacetate extract showed seven spots with $R_{f}$ values of $0.16,0.28,0.65,0.81,0.88,0.90$ and 0.91 while the methanol extract showed thirteen spots along side with $\mathrm{R}_{\mathrm{f}}$ values of $0.16,0.24,0.29,0.36,0.42,0.47,0.51$, $0.54,0.57,0.63,0.66,0.76$ and 0.81 respectively (Figure 2).

\section{Discussion}

The results of the phytochemical screening showed various classes of the secondary metabolites in the $D$. carota aerial parts (Table 1). The n-hexane, ethylacetate and methanol extracts revealed the absence of alkaloids, cardiac glycosides and anthraquinone while steroids/ triterpenes were present in the extracts. However, the steroids/triterpenes may be investigated for possible pharmacological activities such as antioxidant and antiinflammatory properties. The ethylacetate and methanol extracts showed the presence of saponins, flavonoids and tannins (Table 1) which indicated its potential as antioxidant, antimicrobial, hepatoprotective and antiinflammatory properties. The TLC which is a simple and cheap method for detection of plant active constituents revealed the various degree of separation and richness of the extracts.

The proximate analysis (Table 2) showed the nutritional potentials of the D. carota aerial parts such as the moisture

Table 2. Proximate analysis of Daucus carota aerial parts

\begin{tabular}{lllllll}
\hline Parameters & \%Moisture & \%Carbohydrate & \% Crude fibre & \%Crude protein & \% Crude lipid & \%Ash content \\
\hline Values & $10.23 \pm 0.01$ & $51.81 \pm 0.65$ & $9.07 \pm 0.38$ & $14.59 \pm 1.00$ & $10.37 \pm 0.55$ & $12.99 \pm 0.05$ \\
\hline
\end{tabular}

Values are means \pm standard deviation (SD) of triplicate samples.

Table 3. Percentage of antioxidant activity of different extracts in the Daucus carota aerial parts

\begin{tabular}{|c|c|c|c|c|}
\hline Concentration & Hexane extracts & Ethyl acetate extracts & Methanol extracts & Gallic acid (Positive control) \\
\hline $250 \mu \mathrm{g} / \mathrm{mL}$ & $-8.30 \pm 1.56$ & $85.21 \pm 2.14$ & $82.86 \pm 19.78$ & $75.00 \pm 2.00$ \\
\hline $125 \mu \mathrm{g} / \mathrm{mL}$ & $-17.47 \pm 4.56$ & $32.75 \pm 1.85$ & $62.39 \pm 17.98$ & $58.00 \pm 3.10$ \\
\hline $50 \mu \mathrm{g} / \mathrm{mL}$ & $-25.78 \pm 4.00$ & $2.10 \pm 0.47$ & $20.65 \pm 5.77$ & $40.00 \pm 5.00$ \\
\hline $25 \mu \mathrm{g} / \mathrm{mL}$ & $-27.92 \pm 4.79$ & $-12.99 \pm 2.86$ & $16.80 \pm 0.15$ & $20.00 \pm 0.00$ \\
\hline $10 \mu \mathrm{g} / \mathrm{mL}$ & $-28.34 \pm 2.47$ & $-21.66 \pm 1.37$ & $13.03 \pm 0.12$ & $15.00 \pm 4.00$ \\
\hline $5 \mu \mathrm{g} / \mathrm{mL}$ & $-34.72 \pm 0.27$ & $-27.66 \pm 3.57$ & $7.56 \pm 0.36$ & $12.00 \pm 0.90$ \\
\hline $\mathrm{EC}_{50}$ & 490.74 & 86.29 & 166.79 & 211.14 \\
\hline
\end{tabular}

Values (\%) are means \pm standard deviation (SD) of three determinations. 


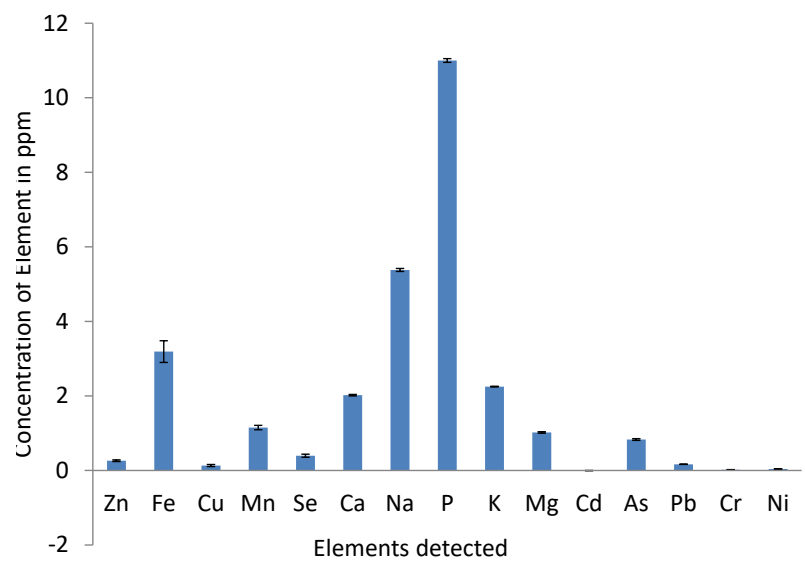

Figure 1. Elemental composition in the aerial parts of Daucus carota.
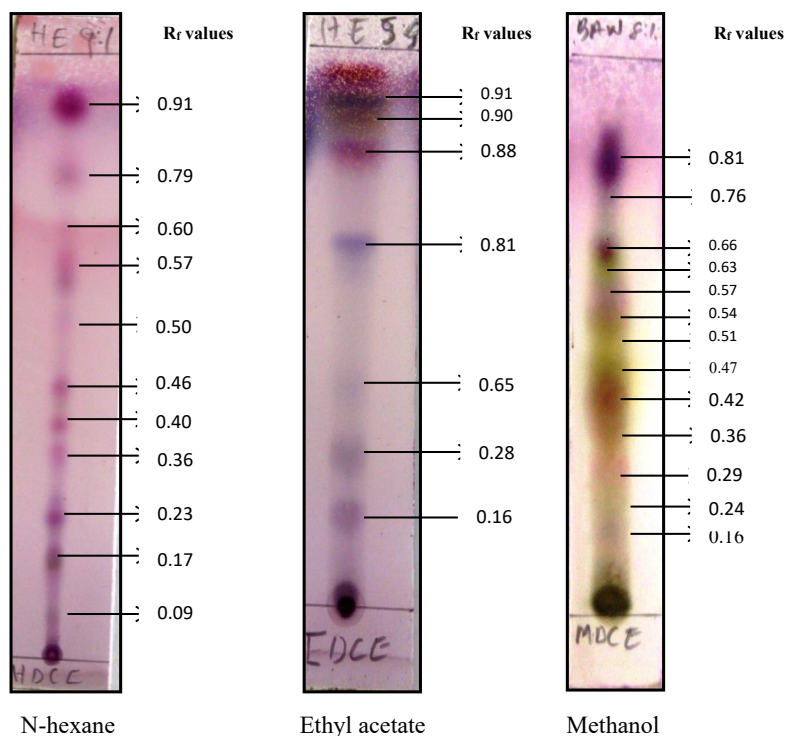

Figure 2. Chromatogram of the Daucus carota aerial parts extracts.

content (10.23\%), carbohydrate (51.81\%), crude protein (14.59\%), crude fibre $(9.07 \%)$, lipid content (10.37\%) and ash content (12.99\%) which shows that it could be good source of food and may contribute to daily nutritional requirement of a person (20-22). This result is comparable to other findings on proximate and mineral compositions of some leafy vegetables consumed in Nigeria and nutraceutical potential of some fruits peels as sources of vegetables $(21,23,24)$. Fifteen mineral elements detected (Figure 1) showed that D. carota aerial parts contain macro and trace elements that could function during muscle contraction, bone formations, growth, metabolism, osmotic balance, regulatory processes activation and other organic bimolecular activities. The presence of heavy metals such as $\mathrm{As}, \mathrm{Ni}, \mathrm{Cd}, \mathrm{Pb}$ and $\mathrm{Cr}$ could be attributed to the toxic components but with the use of good agricultural practices, lower use of chemicals and fertilizer, the toxic components might be prevented or reduced without any harmful effects when ingested over a long period of time (25).

The antioxidant activity of the $D$. carota aerial parts (Table 3) showed that ethylacetate and methanol extracts had the best antioxidant activity with the $\mathrm{EC}_{50}(86.89 \mathrm{ug} /$ $\mathrm{mL}$ and $166.79 \mathrm{ug} / \mathrm{mL}$ ) respectively. Both ethyl acetate and methanol extracts had dose dependent antioxidant activity probably because of their phenolic constituents in the aerial parts $(26,27)$. The antioxidant activity in the extracts may be explored for further pharmacological activities.

\section{Conclusion}

Daucus carota aerial parts are rich in nutrients that could be used as livestock feed supplements and vegetables for mankind. Its utilization could be incorporated in daily diets and boost food security in developing countries with significant poverty indices. However, its further pharmaceutical utilization and toxicity should be investigated for safety.

\section{Authors' contributions}

EA, AA and IG conceived the idea and designed the study. VA and MZ assisted during the literature search and preparation of the manuscript. All authors read the manuscript and confirmed the publication for final version.

\section{Conflict of interests}

The authors declare no conflict of interest.

\section{Ethical considerations}

Ethical issues have been observed by the authors.

\section{Funding/Support}

This research had no financial support.

\section{References}

1. Cragg GM, Newman DJ. International Collaboration in Drug Discovery and Development from Natural Sources. Pure Appl Chem. 2005;77(11):1923-42. doi: 10.1351/ pac200577111923.

2. Elujoba AA, Odeleye OM, Ogunyemi CM. Traditional Medicine Development from Medical and Dental Primary Health Care Delivery System in Africa. Afr J Tradit Complement Altern Med. 2005;2(1):46-61

3. Etkin NL. Edible Medicine: An Ethnopharmacology of Food. Teuson: University of Arizona Press; 2007:201-20.

4. World Health Organization. Traditional Medicine. WHO Fact Sheet No. 134. Geneva: WHO; 2003.

5. Sofowora A. Medicinal Plants and Traditional Medicine in Africa. Ibadan, Nigeria: Spectrum books Ltd; 1993:191-289.

6. Halliwell B. Free radicals, antioxidants, and human disease: curiosity, cause, or consequence? Lancet. 1994;344(8924):721-4. doi: 10.1016/S01406736(94)92211-X. 
7. Shebis Y, Iluz D, Kinel-Tahan Y, Dubinsky Z, Yehoshua Y. Natural antioxidants: function and sources. Food Nutr Sci. 2013;4(6):643-9. doi: 10.4236/fns.2013.46083.

8. Bao B, Chang KC. Carrot juice color, carotenoids, and nonstarchy polysaccharides as affected by processing conditions. J Food Sci. 1994;59(6):1155-8. doi: 10.1111/ j.1365-2621.1994.tb14665.x.

9. Ross IA. Medicinal Plants of the World, volume 3, Chemical Constituents, Traditional and Modern Uses. New Jersey: Humana Press Inc; 2005.

10. Kataria D, Chahal KK, Kaur P, Kaur R. Carrot plant-A potential source of high value compounds and biological activities: A review. Proceedings of the Indian National Science Academy. 2016;82(4):1237-48. doi: 10.16943/ ptinsa/2016/48573.

11. AyeniEA,Ahmad A, Ibrahim G, Vallada A.Pharmacognostic evaluation of Daucus carota Linn. leaf (Apiaceae). Journal of Pharmacognosy and Phytochemistry. 2017;6(5):2400-5.

12. Brain DR, Tuner TD. Extraction procedures. In: The Practical Evaluation of Phytopharmaceuticals. UK, Bristol; 1975:1-107.

13. Harborne ZB. Phytochemical methods: A Guide to Modern Techniques of Plant Analysis. 3rd ed. London: Chapman and Hall Press; 2009:1-283.

14. Stahl E. Thin Layer Chromatography: A laboratory handbook. New Delhi, India: Springer India Private Limited; 2005:1041.

15. AOAC. Official Methods of Analysis of the Association of Analytical Chemists International. 18th ed. Gaithersburg, MD, USA: AOAC; 2005.

16. Idoko O, Emmanuel S, Aguzue O, Fausat A, Osuagwu I, Asuquo T. Phytochemical sreening, proximate analysis and mineral composition of some leafy vegetables consumed in Nigeria. Int J Adv Chem. 2014;2(2):175-7. doi: 10.14419/ ijac.v2i2.3514

17. Mgbemena NM, Obodo GA. Comparative Analysis of Proximate and mineral composition of Moringa oleifera root, leave and seed obtained in Okigwe Imo State, Nigeria.
J Mol Stud Med Res. 2016;1(2):57-62. doi: 10.18801/ jmsmr.010216.07.

18. Akinmoladun AC, Ibukun EO, Afor E, Obuotor EM, Farombi EO. Phytochemical constituent and antioxidant activity of extract from the leaves of Ocimum gratissimum. Sci Res Essays. 2007;2(5):163-6.

19. Mensor LL, Menezes FS, Leitao GG, Reis AS, dos Santos TC, Coube CS, et al. Screening of Brazilian plant extracts for antioxidant activity by the use of DPPH free radical method. Phytother Res. 2001;15(2):127-30. doi: 10.1002/ ptr.687.

20. Asaolu SS, Adefemi OS, Oyakilome IG, Ajibulu KE, Asaolu MF. Proximate and Mineral Composition of Nigerian Leafy Vegetables. J Food Res. 2012;1(3):214-8. doi: 10.5539/jfr. v1n3p214.

21. Imran M, Talpur FN, Jan MI, Khan A, Khan I. Analysis of nutritional components of some wild edible edible plants. J Chem Soc Pak. 2007;29(5):500-5.

22. FAO/WHO. Vitamin and mineral requirements in human nutrition. Bangkok, Thailand: FAO/WHO; 1998.

23. Akindahunsi AA, Salawu SO. Phytochemical screening and nutrient-anti-nutrient composition of selected tropical green leafy vegetables. Afr J Biotechnol.2005;4(6):497-501.

24. FD Romelle, Ashwini-Rani P, RS Manohar. Chemical composition of some selected fruit peels. Eur J Food Sci Technol. 2016;4(4):12-21.

25. Soetan $\mathrm{KO}$, Oyewole OE. The need for adequate processing to reduce the anti-nutritional factors in plants used as human foods and animal feeds: A review. Afr J Food Sci. 2009;3(9):223-32.

26. Sudewi S, Wahyuono S, Astuti P. Isolation and identification of free radicals scavenger from Daucus carotal leaves. Traditional Medicine Journal. 2014;19(3):142-8.

27. Mohammedi H, Mecherara-Idjeri S, Foudil-Cherif Y, Hassani A. Chemical composition and antioxidant activity of essential oils from Algerian Daucus carota L. subsp. Carota aerial parts. Journal of Essential Oil Bearing Plants. 2015;18(4):873-83. doi: 10.1080/0972060X.2015.1010596. 